\title{
Still around the issue of writing in higher education: teaching and research demands ${ }^{1}$
}

\author{
Juliana Alves Assis* \\ Sophie Bailly** \\ Manoel Luiz Gonçalves Corrêa***
}

Writing in higher education provides a wide research field, an interest which is reflected, for instance, in the increasing number of Brazilian and international journals entirely devoted to this topic (in this respect, among others, we point out Linguagem em (Dis)curso, 6, 2006; Lidil, 41, 2010; Pratiques, 153-154, 2012; Scripta, 24, 2009, and 30, 2012; Mélanges Crapel, 37/1, 2016; Trama, 28, 2017; Revista do Gel, 14, 2017). This scenario is also reinforced by the significant amount of books, dissertations and theses addressing issues related to writing practices in the context of higher education institutions in Brazil and abroad.

These publications (meaning not only those mentioned) evidently are based on theoretical principles and even work agendas which do not necessarily match. As such, diverse approaches or perspectives come into play - socio-rhetorical, discursive, socio-anthropological, ethnographic, among others, guided by didactic concerns or not - when studying issues related to academic writing.

Even though the diversity of the theoretical frameworks and methodological approaches in these pieces of research work is clear, it should be noted that they share the understanding that writing is still the main form of record in our culture (CORREAA, 2004), despite being increasingly blended with various other forms of record due to the possibilities opened by digital technologies. These forms include static images, moving images and sounds, as we can experience it daily in our contact with diverse texts on the web.

1 In this text, we aim to address topics related to the project sponsored by Capes-Cofecub called "Discurso acadêmico na pesquisa e no ensino: questões em torno da apropriação da palavra de outrem" (Academic discourse in research and teaching: about appropriating other's words) (N. 834/15), which is also featured in the organization of this edition of the journal Scripta.

* Pontifícia Universidade Católica de Minas Gerais - PUC Minas (Brasil). Bolsista de produtividade em pesquisa $\mathrm{CNPq}$ - nível 2.

** Laboratoire ATILF CNRS UMR 7118, Equipe CRAPEL, Université de Lorraine (França).

*** Universidade de São Paulo - USP (Brasil). Bolsista de produtividade em pesquisa CNPq - nível 2. 
In higher education, this form of record is subject to regulations, some of which are explicitly guided by prescriptive parameters presented in academic writing guides, ${ }^{2}$ constructed in and by means of the complex and heterogeneous range of activities which mark academic practices. This diversity also applies to the domain of disciplines, i.e., the different fields of knowledge represented in higher education. Additionally, these regulations reflect the dialog between higher education institutions (HEI) practices and other instances, such as HEI research funding and assessment bodies, scientific journal committees, etc. This shows that recognizing what academic writing is - and what it should be like - occurs by means of an institutional frame enabled to do so (BOCH, 2014), which does not imply absolute convergence between institutions (and its discursive practices) comprised in this frame, such as those listed above.

The scenario described so far stretches between two poles, as Grossmann (2015) reminds us. On one hand, we see the idea of uniqueness in scientific work, which comprises the writing practices established in this kind of work (sometimes almost creating a direct correspondence between working and speaking). According to that author, the logic underlying this point of view is based on "a uniqueness premise, essentially related to the universality of scientific thinking or, even more broadly, the existence of general principles ruling human cognition"3 (GROSSMANN, 2015, p. 100). On the other hand, the reality and diversity of scientific practices, which account both for the distinction of fields of study and the well-known dichotomies surrounding the history of science (for instance: sciences versus humanities; basic versus applied sciences; quantitative versus qualitative methodology). Evidently, this will also come true in the textualization processes of scientific work (GROSSMANN, 2015).

As can be assumed from the scenario briefly described up to this point, instruction in higher education comprises instruction in and through academic writing, achieved by means of a long, remarkably dialogic socialization process, with all tensions that may be implied. This process is driven by the expectations

2 Working on conventions related to academic literacy has granted some visibility to the authors who deal with this topic. Several books, blogs and other websites teach how to write reviews, summaries and so many other genres among those called academic genres. However, despite being undoubtedly useful, they encounter a coercion towards conventions, a way of working which can mean mere acculturation, since it suppresses the role of social practices familiar to the students and the genres which they already know.

3 Whether duly or unduly, as Grossmann (2015, p. 100) underlines, such principles testify to the "universality of logic rules, which rule above the contingencies of linguistic expression". 
and parameters of this new discursive community where the student is now inserted. Additionally, we should not forget that this community, such as many others, is marked by a hierarchic organization, which distinguishes the experienced researcher from the student researcher. For the latter, we could actually think of a new hierarchic distribution, starting from the undergraduate student in their first years; then, at the end of their course; considering also the distinction between those who perform undergraduate research and those who either do not have or deprive themselves of this opportunity; then, the master student and, finally, the doctorate student, who would be at a higher rank in the community.

This separation between positions in the scientific community is reflected in Reuter's (2004) proposition, which distinguishes research writing as the one which produces and spreads knowledge in a given scientific community, and student research writing, whereby students receive instruction for research. In a dialog with Reuter's proposition, Delcambre \& Lahanier-Reuter (2015, p. 229230) regard the tension between the positions of student researcher and expert researcher as a "likely explanation for difficulties faced by the students, who find themselves in a contradictory and unstable position [...]".

It should be noted that these difficulties are deemed here to be natural parts of the student's integration process in HEIs and, therefore, refute the myth of the student who is ready to write at university or the deficit culture, which many authors working with academic literacy studies have also opposed (among others, LEA; STREET, 2006; HENDERSON; HIRST, 2006; FIAD, 2014).

The perspective assumed by us to discuss writing in higher education also aligns with Hyland's (2012), since we consider that the discursive practices developed in this environment (through lessons, conferences, seminars, professors' feedback about texts written by students, etc.) are means for the students to enter into academic writing, a condition which leads to (re)significance of practices, values, rules and beliefs of a given field of study by the students. Put otherwise, as the students experience everyday practices in university life, they begin to assimilate discourses, genres, knowledge, values and points of view of the scientific field to which they belong. In the course of this process, "they begin to use the discourses and comprehension of this discipline to build a self which could earn recognition and reinforcement by using these resources" (HYLAND, 2012, p. 3).

We are not unaware of the important role of ethnographic research in Applied Linguistics and, in particular, in literacy(ies) studies. Holding on to the perhaps 
most remarkable influence in Brazil, we would like to review a few critical comments by Lillis \& Scott (2007) about the idea of academic literacies, proposed by Lea $\&$ Street (2006). Seeking to define the research about academic literacies, the commenters approach three issues: epistemology, ideology and strategy.

Let us start with the latter: the issue of strategy. The authors consider the singular or plural usage in the expression "academic literacy/ies" as an argumentative thread. This dispute is resolved in the paper by the contrast (followed by association) of the positions of Gunther Kress, Semiotics and Education professor at the Institute of Education, University of London, and the anthropologist Brian Street, whose career has been marked by his activity as a Language and Education professor at the King's College of London, standing out as one of the main theorists of New Literacy Studies. The former argues in favor of using the expression in the singular, stating that, since language and literacy are phenomena which take place in the social environment, variations are due both to language and to literacy, dismissing particular designations:

"If we assume that language is dynamic because it is constantly being remade by its users in response to the demands of their social environment, we do not then have a need to invent a plurality of literacies: it is a normal and absolutely fundamental characteristic of language and literacy to be constantly remade in relation to the needs of the moment; it is neither autonomous or stable, and nor is it a single integrated phenomenon; it is messy and diverse and not in need of pluralizing" (KRESS, 1997, p. 115, apud LILLIS; SCOTT, 2007, p. 15).

Holding on to the perspective supported by the other party in the dispute, the authors relate Street's position to that of Kress, stating that using the expression in the plural does not deny the dynamism of language, with the further advantage of having a strategic function. They quote Street himself, according to whom the argument of plural literacies is a strategic argument, given that certain

"agencies present literacy as the panacea to social ills and the key ingredient in modernization; the dominant assumption has been of a single autonomous literacy that is the same everywhere and simply needs transplanting to new environments" (STREET, 2003, p. 80, apud LILLIS; SCOTT, 2007, p. 16). 
From the comment about this dispute, that the authors argue that plurality of literacy correlates to heterogeneity of language, thus recognizing it as a matter of strategy.

In their effort to define research about academic literacies by pointing out epistemological, ideological and strategical issues, the authors relate the ideological aspect to the educational myths described by Kress (2007). Namely: the myths of "homogeneity of the student population", "stability of disciplines", and "unidirectionality of the teacher-student relation" (apud LILLIS; SCOTT, 2007, p. 13). The authors suggest that building research upon these myths leads to mainly

"identifying academic conventions - at one or more levels of grammar, discourse or rhetorical structure or genre - and on (or with a view to) exploring how students might be taught to become proficient or 'expert' and developing materials on that basis" (LILLIS; SCOTT, 2007, p. 13).

In turn, they argue that:

"a transformative approach in contrast involves an interest in such questions but in addition is concerned with: a) locating such conventions in relation to specific and contested traditions of knowledge making; $b$ ) eliciting the perspectives of writers (whether students or professionals) on the ways in which such conventions impinge on their meaning making; c) exploring alternative ways of meaning making in academia, not least by considering the resources that (student) writers bring to the academy as legitimate tools for meaning making" (LILLIS; SCOTT, 2007, p. 13).

Therefore, in regard to ideology, these are the arguments which lead the authors to embrace the view that, in academic literacies research, "the ideological stance towards the object of study [...] can be described as explicitly transformative rather than normative" (LILLIS; SCOTT, 2007, p. 12).

Finally, concerning issues of epistemology, the empiric methodology of an ideological model of literacy is ethnography. That methodology simultaneously involves "observation of the practices surrounding the production of texts - rather than focusing solely on written texts - as well as participants' perspectives on the texts and practices" (LILLIS; SCOTT, 2007, p. 11). 
Again, according to the authors, research in academic literacies has placed

"the emphasis away from texts, towards practices, drawing on a number of traditions; New Literacy Studies informed by anthropology (see for example Street, 1984, 2003; Baynham, 1995), critical discourse studies (notably the work of Fairclough, 1992, 1995) and the sociology of knowledge" (Latour and Woolgar, 1986) (LILLIS; SCOTT, 2007, p. 11).

Thus, we can see how academic literacies research develops epistemologically through a given concept of practice and a particular view on text and learning.

Concerning the concept of practice, the authors explain that it "offers a way of linking language with what individuals, as socially situated actors, do" (LILLIS; SCOTT, 2007, p. 11), in three different ways:

(a) "an emphasis on practice signals that specific instances of language use - spoken and written texts - do not exist in isolation but are bound up with what people do - practices - in the material, social world";

(b)"that ways of doing things with texts, become part of everyday, implicit life routines both of the individual, habitus in Bourdieu's (1991) terms, and of social institutions";

(c) "by engaging in an existing practice we are maintaining a particular type of representational resource; by drawing on a particular type of representational resource, we are maintaining a particular type of social practice" (LILLIS; SCOTT, 2007, p. 12).

As can be observed, the idea of practice, in relation to literacy, conceptualizes, in the words of Barton \& Hamilton, "the link between the activities of reading and writing and the social structures in which they are embedded and which they help to shape" (BARTON; HAMILTON, 1998, p. 6, apud LILLIS; SCOTT, 2007, p. 12).

The way the authors conceive research in academic literacy involves an epistemological change of particular interest to Applied Linguistics. Viewed from the perspective of practice, language cannot be separated from what individuals do. This form of access to knowledge about practices (and literacies) is a significant epistemological change, and we believe that, in terms of language,

4 It is worth remembering that the state of "situated" refers both to the "context of situation" and the "context of culture", in the terms of Malinowski (1979), meaning that language does not dissociate from action. (Cf. LILLIS; SCOTT, 2007, p.11.) 
only a discursive perspective would be broad enough to span this complexity. Still, the applied linguist must decide between "ethnographic linguistics", as supported by the authors, and a discursive (thus not only textual) perspective, which, in a link with the historical materiality of meaning, will embrace the ethnographic perspective without reducing it to an appendix. ${ }^{5}$

Regarding the issue of ideology involved, while doing a research about academic literacies, it is not enough to merely record data, transcribe them in detail and analyze the texts prepared precisely for it to take place, nor is it enough to describe this material in terms of concepts of text or discourse genres. Furthermore, according to the authors, for the ideological model of literacy to which they are affiliated, the following is required: a) locating such conventions in relation to traditions of knowledge making; b) eliciting the perspectives of writers on the ways in which such conventions impinge on their meaning making; c) considering the resources that writers bring to the academy as legitimate tools for meaning making. As a result, we have a transformative way of promoting, in the didactic-pedagogic activity, access to academic literacies at the same time as we operate theoretically and methodologically in research about them.

Finally, in regard to issues of strategy, considering the plurality of literacies in association with the heterogeneity of language prevents the belief in immutability of conventions, which are still taken into account, but under a new epistemological perspective which, eventually, links language to the work of mankind. It follows that the theoretical and methodological treatment, which guides research about academic literacies and clarifies the didactic-pedagogic practice enabling access to them, cannot be any less than transformative both in terms of how the research object should be viewed and designed, and how the relations of the students with established conventions should be conceived. Once these steps are fulfilled, the social practices (always loquacious, since there is no work without words) and the texts (social practices and pragmatic-discursive work) give life to literacy, according to the singularities of practices, discourse and subjects.

One last challenge is related to marking the presence of the other in texts. This challenge surfaces on the texts, given that, in academic genres, reference to the sources is mandatory, regardless of the process efficacy and quoting procedures, since there will always be suppressed voices. Thus, we mean the usage and role of other's discourse in the academic text, often the "voice" of an expert member of 
the academic community, a condition evidently reflected in the way the author's position is drawn, as a kind of choir conductor of the voices brought to the academic text.

These reflections take us back to the role of HEIs when it comes to the current writing challenges in university education, whatever may be the education steps encompassed by higher education (undergraduate, specialization, master, doctorate studies). They also provide the foundation for a special thematic edition of the journal Scripta dedicated to writing practices in academic-scientific life.

$* * * * * *$

\section{Introduction to the Dossier}

The dossier Escrita no Ensino Superior: ensino e pesquisa (Writing in Higher Education: teaching and research) is organized in three thematic sections covering important aspects of the discussion about writing in higher education, according to the interests of the project Discurso acadêmico na pesquisa e no ensino: questões em torno da apropriação da palavra de outrem (Academic discourse in research and teaching: about appropriating other's words) (Capes-Cofecub public notice), involving some contributing authors of this edition of the journal Scripta.

The first section, comprising papers by Bertrand Daunay, Isabelle Delcambre, Eliane Gouvêa Lousada, Adriana Zavaglia, Olivier Dezutter and Danytiele Cristina Fernandes de Paula, covers issues about the relation with other's words in academic writing, regardless of it being related to the author's position or supporting a point of view or not.

In Les modalités énonciatives de la reprise du discours d'autrui dans les écrits de recherche et les écrits didactiques, Bertrand Daunay and Isabelle Delcambre perform a comparative study of enunciative modalities of other's discourse appropriation in two different kinds of texts written by university professors: didactic texts, developed for distance learning, and scientific texts, i.e., texts in which research results are published. Considering the results presented by the research, the authors relate both the differences and convergences between these two kinds of texts to their socio-historical conditions of production and circulation.

In the work Se former à la rédaction de la note de lecture en contexte 
universitaire, Eliane Gouvêa Lousada, Adriana Zavaglia and Olivier Dezutter discuss the results of a writing experience in the genre "note de lecture" carried out with Brazilian undergraduate students of Literature and French as a foreign language, in French language classes. The authors highlight that this genre is ubiquitous in the university context, since it is used by professors to assess the students' reading competence, furthermore pointing out its potential for developing skills of summarizing as well as developing and supporting a point of view.

In her work A questão da identidade na escrita acadêmica, Danytiele Cristina Fernandes de Paula provides a bibliographic review about identity in academic writing, particularly in regard to its relation with other's discourse, which marks this kind of text. Thus, the quotation is approached both in its dialogic and its esthetic dimension, as opposed to a strictly prescriptive view.

The second section of the dossier includes papers by authors dealing with devices and resources in distance and/or classroom learning, focusing on academic writing teaching/learning in different contexts. The authors are as follows: Maria Ignacia Dorronzoro, Maria Fabiana Luchetti, Maria Sílvia Cintra Martins, Cristina Becker Lopes Perna, Lucas Zambrano Rollsing, Rafael Padilha Ferreira, Eulália Vera Lúcia Fraga Leurquin, Karla Maria Marques Peixoto and Kariny Cristina Souza Raposo.

In the text called Dispositivos didácticos para la enseñanza-aprendizaje del lenguaje escrito en la universidad: algunos lineamientos para su elaboración, Maria Ignacia Dorronzoro and Maria Fabiana Luchetti present a set of theoretical and methodological guidelines for teaching/learning disciplinary content in humanities. These guidelines, aligned with a Vygotskian socio-cultural perspective and developed at the Universidad Nacional de Luján (Argentina), underline the relation between disciplinary content and the discourse forms by which thinking in each field of knowledge takes place.

In the paper called Letramento acadêmico e oralidade: repensando termos à luz da presença indígena nas universidades brasileiras, Maria Sílvia Cintra Martins creates a parallel between the discussions about academic literacy and the contemporary Brazilian reality, concerning the presence of indigenous students in universities. Her research is based on procedures and strategies similar to those adopted by Lea \& Street (2006) in the model of Academic Literacies. Based on the research results, the author argues that the model of Academic Literacies is appropriate for subjects coming from minority groups to be successful in accessing hegemonic literacy. 
In the paper $O$ intervalo Escola-Universidade: mais do que uma questão genérica, Cristina Becker Lopes Perna, Lucas Zambrano Rollsing and Rafael Padilha Ferreira deal with the gap in teaching/learning of academic genres originating, among others, from not very productive experiences in basic education with texts related to academic practices. The authors advocate the methodology of Portuguese teaching for academic purposes (in the frame of the experiences with English for Academic Purposes), considering its potential to offer the student significant experiences for their education and future professional activity.

A escrita no ensino superior e os efeitos do desenvolvimento profissional na formação do professor de língua materna is the title of Eulália Vera Lúcia Fraga Leurquin and Karla Maria Marques Peixoto's paper, in which the authors reflect on apprentice writing in the course of Letters, in and outside the classroom. For this reason, the teaching apprenticeship reports serve as relevant corpus in this social and professional environment. The analyzed data suggests that the apprenticeship report is an important tool for the analysis of the apprentice's work, since it reveals different dimensions of this education stage.

In the text Práticas e eventos de letramentos no contexto de uma disciplina na modalidade semipresencial, Kariny Cristina Souza Raposo deals with a description and analysis of literacy practices and events in a discipline offered in a blended learning system in Law, Management and Civil Engineering at a University Center in the state of Minas Gerais (Brazil). The discipline, called Text Reading and Production, relies on the forum genre as one of its teaching/learning resources. In her analysis, Kariny Raposo studies the role of the forum in the process of integrating students into academic discursive practices.

Didier Colin, Catherine Dolignier, Estela Raquel Klett, Márcia Sipavicius Seide, Lucía Antonia Natale, Hermano Aroldo Gois Oliveira and Denise Lino de Araújo form the third and last section of the dossier work, dealing with representations about reading and teaching practices in higher education. Based on work developed on the field of writing didactics associating student difficulties to the representations that they make of the learning object, Didier Colin and Catherine Dolignier, in their paper called L'auctorisation d'étudiants de lettres dans l'écriture d'un mémoire de master enseignement, raise questions about the relationship between the concept of authorship by students in France doing their master's degree in French Letters teaching for secondary education and difficulties overcome while writing the master thesis (mémoire de master), regarding the way the author's position is constructed in the genre under consideration. 
In the paper called L'écrit universitaire en français langue étrangère: les savoirs mis en jeu, Estela Raquel Klett aims to reflect on the process of learning French as a foreign language among Spanish-speaking students at the School of Philosophy and Letters of the University of Buenos Aires (Argentina). Based on premises of Social Interactionism, the students' representations about reading and writing at university are analyzed taking into account the discourse genres in circulation in that environment as well as linguistic and socio-cultural knowledge.

A contrastive study about writing and academic literacy concepts developed and reproduced in written comments of two university professors is presented by Márcia Sipavicius Seide and Lucía Antonia Natale in the paper Concepciones de la escritura y de la alfabetización académica en devoluciones escritas de docentes universitarios: un estudio contrastivo. This research, whose corpus uses discourses of a professor from Brazil and another from Argentina, shows some significant differences in writing and academic literacy concepts by these two subjects, which suggests the relevance of including cultural aspects in the discussion about teaching.

Led by an effort to investigate representations about academic writing among university students, in the paper Representações sociais de escrita em curso de formação docente: objeto de ensino e objeto de inserção nas práticas letradas acadêmicas, Hermano Aroldo Gois Oliveira and Denise Lino de Araújo present results of a research developed with Letters undergraduate students of three higher education institutions located in the state of Paraíba (Brazil), drawing on a multimethodological approach based on principles of the Social Representations Theory. The results provide important contributions to the field of academic literacy studies, regarding the role of representations in this process.

In the section Reviews, Fabiano Henrique Rocha discusses the book $O$ internetês na escola (Internetese at School, untranslated), by the authors Fabiana Komesu and Luciani Tenani, which is divided into seven chapters and, beyond defining the "internetês", intends to present possibilities for usage in basic education. Fabiano Henrique Rocha highlights the didactic traces of the book and its relevance for the educational context.

Closing this section, Sibely Oliveira Silva and Érika Dourado Amorelli discuss the book Letramento e formação universitária: formar para a escrita e pela escrita (Literacy and University Education: Educating for and by Writing, untranslated), organized by Fanny Rinck, Françoise Boch and Juliana Alves 
Assis. According to the reviewers, the book, organized in sixteen chapters, offers a relevant contribution both for debating the topic of academic literacy and for education practices and actions in higher education.

Finally, in the section Interviews, Maria Angela Paulino Teixeira Lopes presents notes of the interview with French professor Fanny Rinck about the role of writing in the process of teacher's education in France, revealing particularities and difficulties of this journey. The suggested questions for the interview and the dialog that Fanny Rinck establishes with them provides the reader with a set of knowledge and reflections about academic writing and professional practices.

In sum, the purpose of this thematic edition of the journal Scripta - Escrita no Ensino Superior: ensino e pesquisa - with the featured work is to strengthen study perspectives which could have an impact on didactic devices and pedagogic practices applied in university education as well as help opening possibilities to articulate theoretical and methodological approaches in academic writing studies.

\section{References}

BARTON, David; HAMILTON, Mary. Local Literacies. London: Routledge, 1998.

BAYNHAM, Mike. Literacy Practices: Investigating Literacy in Social Contexts. London: Longman, 1995.

$\mathrm{BOCH}$, Françoise. Former les doctorants à l'écriture de la thèse en exploitant les études descriptives de l'écrit scientifique. Linguagem em (Dis)curso, [S.l.], v. 13, n. 3, p. 543-568, May 2014. ISSN 1982-4017. Available at: <http:// www.portaldeperiodicos.unisul.br/index.php/ Linguagem_Discurso/article/ view/2158/1554>. Accessed on: Nov. 21, 2015.

BOURDIEU, Pierre. Language and Symbolic Power. Translated by G. Raymond and M. Adamson. Cambridge, Mass.: Polity Press, 1991.

CORRÊA, Manoel Luiz Gonçalves. O modo heterogêneo da escrita. São Paulo: Martins Fontes, 2004.

CORRÊA, Manoel Luiz Gonçalves. As perspectivas etnográfica e discursiva no ensino da escrita: o exemplo de textos de pré-universitários. Revista da ABRALIN, v. especial, p. 333-356, 2011. 
DELCAMBRE, Isabelle; LAHANIER-REUTER, Dominique. Discurso de outrem e letramentos universitários. In: RINCK, Fanny; BOCH, Françoise; ASSIS, Juliana Alves (Org.). Letramento e formação universitária: formar para a escrita e pela escrita. Campinas, SP: Mercado de Letras, 2015. p. 225-250 (Série Ideias Sobre Linguagem).

FAIRCLOUGH, Norman. Discourse and social change. Cambridge: Polity Press, 1992.

FAIRCLOUGH, Norman. Critical Discourse Analysis: the critical study of language. London: Longman, 1995.

FIAD, Raquel Salek. Reescrita, dialogismo e etnografia. Linguagem em (Dis)curso, [S.1.], v. 13, n. 3, p. 463-480, May 2014. ISSN 1982-4017. Available at: <http://www.portaldeperiodicos.unisul.br/index.php/Linguagem_Discurso/ article/view/2155/1551>. Accessed on: Feb. 30, 2016.

GROSSMANN, Francis. Por que e como as coisas mudam? Padronização e variação no campo do discurso científico. In: RINCK, Fanny; BOCH, Françoise; ASSIS, Juliana Alves (Org.). Letramento e formação universitária: formar para a escrita e pela escrita. Campinas, SP: Mercado de Letras, 2015. p. 97-128 (Série Ideias Sobre Linguagem).

HENDERSON, Robin; HIRST, Elizabeth. Reframing academic literacy: Reexamining a short course for "disadvantaged" tertiary students. English teaching: practice and critique, v. 6, n. 2, p. 25-38, 2006.

HYLAND, Ken. Disciplinary identities: Individuality and community in academic discourse. New York; Cambridge: Cambridge University Press, 2012.

KRESS, Gunther. Before writing: rethinking the paths to literacy. London: Routledge, 1997.

KRESS, Gunther. Thinking about meaning and learning in a world of instability and multiplicity. Pedagogies. An international journal, v. 1, p. 19-34, 2007.

LATOUR, Bruno; WOOLGAR, Steve. Laboratory life: the construction of scientific facts. $2^{\text {nd }}$ ed. Princeton, NJ: Princeton University Press, 1986.

LEA, Mary. R.; STREET, Brian V. The "Academic Literacies" model: theory and applications. Theory into practice, v. 45, n. 4, p. 368-377, 2006.

LILLIS, Theresa; SCOTT, Mary. Defining academic literacies research: issues of epistemology, ideology and strategy. Journal of Applied Linguistics, v. 4, n. 1, p. 5-32, 2007. Disponível em: 10.1558/japl.v4i1.5, Equinox online. 
MALINOWSKI, Bronislaw. O problema do significado em linguagens primitivas. In: OGDEN, C. K.; RICHARDS, I. A. (Ed.). O significado de significado. 2. ed. Rio de Janeiro: Zahar, 1979. p. 295-330. Original publicado em 1923.

REUTER, Yves. Analyser les problèmes de l'éscriture de recherche en formation. Pratiques, n. 121-122, p. 9-27, 2004.

STREET, Brian V. Literacy in Theory and Practice. London: Cambridge University Press, 1984.

STREET, Brian V. The implications of the new literacy studies for education. In S. GOODMAN, S.; LILLIS, T.; MAYBIN, J.; MERCER, N. (Ed.). Language, literacy and education: a reader. Stoke on Trent: Trentham Books, 2003. 